\title{
Tribal Values and Norms in Mongolia and Their Effect on Women's Status
}

\author{
Shaul M. Gabbay \\ Josef Korbel School of International Studies, University of Denver, Denver, USA \\ Email: shaul.gabbay@du.edu \\ Received 5 March 2015; accepted 23 May 2015; published 26 May 2015 \\ Copyright (C) 2015 by author and Scientific Research Publishing Inc. \\ This work is licensed under the Creative Commons Attribution International License (CC BY). \\ http://creativecommons.org/licenses/by/4.0/

\section{Abstract}

Roughly the size of Alaska, Mongolia is a landlocked country between Russia on its northern frontier and China on its southern border. With just over three million inhabitants, it is sparsely populated, with nearly half of the people living in the capital city of Ulaanbaatar, and in other provincial centers. The tribal networks in Mongolia are the main tenants of social structural characteristics in the society. In this paper, the effect of tribal values and norms on family structures particularly with regards to women is delineated analyzed and discussed. The influence and similarity to Muslim cultural tribal structures in and outside of Mongolia are used in a comparative sociological meta analysis methodology.

\section{Keywords}

\section{Mongolia, Tribes, Values, Women}

\section{Introduction}

Roughly the size of Alaska, Mongolia is a landlocked country between Russia on its northern frontier and China on its southern border. With just over three million inhabitants it is sparsely populated, with nearly half of the people living in the capital city of Ulaanbaatar, and in other provincial centers. The tribal networks in Mongolia are the main tenants of social structural characteristics in the society. In this paper, the effect of tribal values and norms on family structures particularly with regards to women is delineated analyzed and discussed. The influence and similarity to Muslim cultural tribal structures in and outside of Mongolia are used in a comparative sociological meta analysis methodology.

\section{Overview of Mongolia}

Roughly the size of Alaska, Mongolia is a landlocked country between Russia on its northern frontier and China on its southern border. With just over three million inhabitants (2012 estimate) [1], Mongolia is 
sparsely populated, with nearly half of the people living in the capital city of Ulaanbaatar, and in other provincial centers.

Mongolia gained independence from China in 1921. In 1924 it fell under the rule of a Russian Soviet-backed communist regime. In the early 1990s, the communist regime was replaced through peaceful revolution by a nominally democratic system of government which has held regularly scheduled elections since then. Ethnically, 94.43\% percent of the population consider themselves Mongols. A majority of these claim Khalkha tribal/clan ethnicity; 3.8\% percent of Mongols are Turkic in origin. Ethnic Kazakh are the majority people of this minority $3.8 \%$ percent; the remainder of the population includes other tribal ethnicities as well as Chinese and some Russians. Tibetan Buddhist Lamaism is the major religion in Mongolia, though a small percentage of the population practices Islam, Christianity and Shamanism and quite a substantial number, $38.6 \%$, claim to have no religion [2].

Religious and tribal/clan ethnic groups have survived many years of persecution under erstwhile Soviet dominance. In an effort to enhance economic reform during the 1930s and 1940s, the communist regime specifically targeted Mongolia's two most important institutions: religion and the aristocracy. According to the US Department of State, "Between 1932 and 1945, their excess zeal, intolerance, and inexperience led to anticommunist uprisings. In the late 1930s, purges directed at the religious institution resulted in the desecration of hundreds of Buddhist institutions and imprisonment of more than 10,000 people” [2].

Following Mongolia's democratic revolution of 1990, previously held traditional cultural/social conceptions of religious and tribal/ethnic groups in Mongolia continued to play their role throughout the country and its society. Upon becoming a truly independent nation, Mongolians began to struggle with issues of identity, and what it meant to be "Mongolian." Writing for Central Eurasia Studies Review in late 2005, sociologist Alexander Diener argued that the dominant Khalkha ethnic group has been attempting to establish hegemony over all other ethnic groups in the country, as Mongolia struggles with modernization and the traditional, nomadic lifestyle of many of its inhabitants [3]. As the process of modernization continues, tensions between ethnic groups that wish to maintain a traditional lifestyle and those who are pushing for modernity will continue to mount.

\section{Shamanism and Islam in Mongolia}

In the modern "Western World" one social aspect of traditional Mongolian society, Shamanism, is probably the least well known. Therefore, it is useful to briefly describe this societal world-view because of the fact that it continues to play a role in today's Mongolian changing society that is on its trajectory to what is generally viewed as "modernity". As part of the modernizing process in Mongolia includes the influx of individuals from rural Mongolian tribes and clans into Mongolia's cities, and into industrial/mining development areas of the country, ancient beliefs such as Shamanism can cause tensions and frictions for individuals or groups with regard to other individuals and groups who do not, or do not any longer, embrace such beliefs. These beliefs can also cause identity crises for individuals trying to adapt to the "modern" world and friction between them and their children who adapt more readily to new social realities around them that differ from their parent's more traditional tribal and clan values.

One example of seeking to adapt to the "modern" world is the Darhad tribe that originates in a valley named for them in the northern region of Mongolia bordering on Russian Siberia. Largely a nomadic people, members of the Darhad tribe live off the land and survive by herding livestock that includes sheep, goats, cattle, yak and camels.

According to a $2008 \mathrm{BBC}$ report, the effects of modernization and privatization have taken its toll on tribes such as the Darhad. The report notes: "Many rely on entirely their livestock; as incomes have fallen, a third of the population live below the official poverty line. Meanwhile, because the government wants more people to join the modern economy, children from the countryside are encouraged to go to college" [4].

Among the Darhad people, shamanism is the dominant religion. Shamanism, in general, is a system of beliefs that holds to communication with the spirit world. Though practices do differ from culture to culture, Shamans throughout the world hold onto similar viewpoints. Some of these are as follows [4]:

- The spirits can play important roles in human lives.

- The shaman can control and/or cooperate with the spirits for the community's benefit.

- The spirits can be either good or bad.

- Shamans engage various processes and techniques to incite trance; such as: singing, dancing, meditating and drumming. 
- Animals play an important role, acting as omens and message-bearers, as well as representations of animal spirit guides.

- The shaman's spirit leaves the body and enters into the supernatural world during certain tasks.

- The shamans can treat illnesses or sickness.

- Shamans are healers, gurus and magicians.

Although shamanism was banned by Mongolia's communist regime in 1930, it continued to be secretly practiced, despite its being persecuted. Like Buddhism, it regained its erstwhile official legal position in the country following the 1990 democratic revolution. However, the ever-modernizing country has attached a negative stigma on the religion and those who practice it. For modernists, shamanists are seen as backward, they:

"are not necessarily considered enlightened, and often are even feared for their ability to use their power to carry out malicious intent" [4].

Consequently, individuals of the Darhad tribe and members of certain other tribes such as the Western Buryats, and Urianhay, who cling to their traditional shamanistic beliefs, although legally protected, have been discriminated against by the national Government. Such instances have been recognized by international monitoring agencies. According to the 2006 Religious Freedom Report released by the Bureau of Democracy, Human Rights, and Labor, the Mongolian constitution does provide for religious equality:

"However, the law limits proselytizing, and some religious groups faced bureaucratic harassment or were denied registration.

While the government officially recognizes the right to practice shamanism, freedom of expression—religious or political—is in reality extremely limited throughout the country, and has often led to persecution. According to Amnesty International's 2007 Human Rights Report:

"Freedom of expression remained severely restricted. During the year, more than 40 journalists were threatened or attacked, or were harassed or investigated by the authorities". The report continues to add that individuals "were often threatened and discriminated against if they criticized the authorities" [5].

Because of the modernization process that is taking place in Mongolia, which has caused internal migrations from the more remote countryside to the cities and industrial and mining areas of the country, and the consequent greater mixing of ethnic groups it would not be surprising that beliefs such as Shamanism survive, giving comfort to people as it has for thousands of years in Mongolia and has intermeshed itself with Tibetan Buddhist Lamaism, Mongolia's main religion.

Sunni Muslim Kazak's are mainly located in western Mongolia to which they migrated in the $19^{\text {th }}$ century. There is, however, Muslim Kazakh presence in Mongolia's capital Ulan Bator [6]. Since the 1990's tens of thousands of Muslim Kazakh's have migrated to Kazakhstan, their historical homeland, for greater economic opportunities there as well as cultural-religious affinities [7]. More recently, there has also been a smaller reverse flow of Mongolian Muslim Kazakh's returning home to Mongolia from Kazakhstan.

Due to the higher birthrate of Mongolian Muslim Kazakhs vis a vis the rest of Mongolia's non-Muslim population [6], their presence and consequent impact/influence, along with the proselytizing (in Arabic, "Da'awa"call to Islam) tenets of Islam, will increase accordingly.

There is also a Muslim Uighur people presence in western Mongolia with Muslim religious ties to the Kazakhs there, sharing similar religious values and dogmas. Mongolian Muslim Uighurs are connected ethnically and religiously to the Muslim Uighurs in China's northwest province of Xinjiang, which borders on Mongolia, and where they number around nine million people [8], three times the total population of Mongolia.

\section{Socio-Economic Conditions and Honor Based Domestic Violence Affecting Women in Mongolia}

According to a 2006 Human Rights Report issued by the Bureau of Democracy, Human Rights, and Labor, serious issues of human rights abuses exist in Mongolia that include:

"Police abuse of prisoners and detainees; impunity; poor conditions at prisons and pretrial detention centers; arbitrary arrest, lengthy detention, and corruption within the judicial system; criminal defamation laws resulting in self censorship by the press; continued refusal by one province to register Christian 
churches; sweeping secrecy laws and a lack of transparency; endemic domestic violence against women; international trafficking of persons; and some domestic cases of child prostitution" [9].

Moreover, violence against women continues to increase throughout the country. According to the report, much of the abuse originates from the poor economic conditions, which have driven many men to alcoholism and violence. "In recent years, economic and societal changes created new stresses on families, including loss of jobs, inflation, and lowered spending on social and educational programs. Some statistics showed that more than 60 percent of family abuse cases were related to alcohol abuse” [9].

Confirming the ongoing violence against women in Mongolia the United Nations High Commissioner for Refugees (UNHCR) refers to the US Department of State 2011 Human Rights Report: Mongolia, which states that although the Mongolian criminal code outlaws rape there is:

"However, no law specifically prohibits spousal rape, which is commonly not recognized or prosecuted. Victims were often stigmatized and accused of not fulfilling their marital duties. As a result many NGOs blamed law enforcement officials for spousal rape victims' silence" [10].

The same 2011 US State Department Human Rights Report referred to by the UNHCR goes on to report that:

"Domestic violence remained a serious problem, particularly against women of low-income rural families. The law requires police to accept and file complaints, visit the site of incidents, interrogate offenders and witnesses, impose administrative criminal penalties, and bring victims to refuge. It also provides for sanctions against offenders, including expulsion from the home, prohibitions on the use of joint property, prohibitions on meeting victims and on access to minors, and compulsory training aimed at behavior modification. However, this level of service was rarely provided because the police lacked sufficient funding and, according to NGOs, were often reluctant to intervene in what was viewed as an internal family matter.

Arrestees were sometimes held under an administrative penalty law rather than for domestic abuse, in which case they were fined 15,000 tugrik (\$11) and detained for up to 72 hours before being released. In addition domestic violence cannot be reported anonymously; callers must give their names and location, thereby dissuading individuals from reporting domestic abuse due to fear their identity might be leaked to the perpetrator.

In 2010 there were 1242 reported cases of domestic violence, nearly double the 720 in the previous year. The National Center against Violence (NCAV) believed that this was likely due to increased awareness of the resources available as a result of media campaigns about recent legislation changes. There have never been any domestic violence convictions due to the fact that, while domestic violence legislation exists, there is no implementing provision in the criminal code. Offenders are prosecuted under other criminal codes involving assault, infliction of injury to health, disorderly conduct, or hooliganism. The NCAV reported that of 18 clients requesting restraining orders, only two of the requests were granted. Moreover, the law fails to assign responsibility to particular agencies to execute restraining orders. The Mongolian Women's Legal Association reported that, as a result, restraining orders were poorly monitored and enforced. The law states restraining orders can be in effect only as long as victims are in a shelter, thus exposing them to danger upon their release" [10].

The UNHCR referring to a report in 2011 by Minorities Rights Group International reported that:

“...domestic violence remains a critical but taboo issue in Mongolia, in the absence of laws prohibiting marital rape. Facilities are limited for victims of sexual and gender-based violence in remote areas, where most minority groups reside. In spite of the government's efforts, poor implementation of existing legislation still reflects the lack of political will to tackle these issues, while women continue to face social, economic and procedural barriers in accessing state protection, according to the Common Country Assessment conducted by the UN in Mongolia in 2010. This is even more the case for minority women. Young women from rural areas (where most minority communities live) remained most vulnerable to trafficking and abduction for commercial sexual exploitation" [11].

In addition to domestic violence against women in Mongolia, the country lacks a stable support system in terms of healthcare and employee benefits; this issue in the post-communist era has affected women particularly adversely. According to Asian historian and Professor Morris Rossabi, because of "privatization and the selling 
off of government enterprises, women in the labor force became far more vulnerable than before.” Moreover, "Unemployment often had devastating consequences; although gender breakdowns for the unregistered unemployed are difficult to obtain, collateral evidence suggests that joblessness had more effects on women” [12]. Alluding to an interview with one Mongolian woman, Rossabi demonstrates the general feeling among Mongolian women concerning healthcare. As one woman put it, "[m] edical service is bad here. In fact, there is really no treatment at all” [12].

Resources throughout Mongolia are limited and unequally distributed, consequently the government has been unable to uphold the social benefits regulations it provides for in its constitution. This has led to poor working conditions, especially for women working within the private sector where sexual harassment is a widespread problem exacerbated by traditional attitudes and the risk of unemployment. The United States Department of State reports that of unemployed women under the age of 35, one-half were self-reported victims of workplace sexual harassment” [13].

Consequently, in order to make ends meet a growing number of women have turned to prostitution, which has correlated with the increase of violence against and sexual trafficking of women [14]. Conditions in Mongolia are dismal for single-parent families headed by women, which is overwhelmingly the case for single parent families in the country. In the modernizing economy, these women are consistently marginalized. The Mongolian Government, in spite of official proclamations has been, according to human rights observers such as the US State Department, in reality ineffective in its attempts to remedy the issues these women face [15].

In consequence of the aforementioned, general conditions for women and often for their children, in Mongolia, is consistently to say the least, not a favorable one. In fact, Mongolia is a country where violence against women is historic and, in spite of official government rhetoric, proclamations and laws to the contrary, it remains presently an endemic issue in Mongolian society. Such violence is committed with impunity against women in general, as well as against single parent women and their young children, without fear by its perpetrators of significant punishment by Mongolian police forces or by Mongolia’s judiciary, especially when such violence is committed within the home of the victims. The reality of this ongoing societal phenomenon in Mongolia is a clear and heartbreaking reality.

Although not officially acknowledged in Mongolia, in fact tribal/clan differences that do exist in Mongolian marriages are only exacerbated when these marriages fall apart. The ultimate animosity that inter-tribal marriages suffer when they disintegrate is often aggravated by historical and ongoing societal tribal/clan tensions.

When women give birth only to daughters and not to sons, or even just one son, it makes matters only worse in a patriarchal society where a male heir is indispensable for a man's honor and his stature in society, as well as for the honor and stature of a man's immediate and extended family. In Mongolian society a man's honor and manhood often come into question when his wife is incapable of giving him a son, a male heir. Consequently, a Mongolian man, in his cultural mindset, feels his manliness and male honor threatened by his wife when she is incapable of giving him a son and to react to this threat with "justified" acts of violence against his wife. His sense of impunity, when committing acts of domestic violence, is only enhanced by the realty of Mongolia's male dominated society where police avoid becoming involved in domestic violence cases [16], as similarly regularly occurs in Muslim societies. Although not predominantly Muslim, Mongolian tribal society shares some of the traditional tribal Arab Muslim values regarding the position of women in society.

Based on many years of personal advanced studies about societal and tribal/clan networks, such as exist in Mongolia and in other parts of the world that includes Arab Muslim societies, time does not diminish a man's anger towards a wife's perceived failings when it comes to issues that he considers as an affront to his honor-whether it is a failure to produce a son or caused by some other "crime" such as infidelity on the part of the wife. In Mongolia's tribal society such an affront to honor is not just a personal matter since it reflects, as it does also in most Arab Muslim societies, on a man's extended family's, on his clan's and on his tribe's honor as a whole.

It can be rather easily argued that a man's desire for violent retribution in such "honor" societies has incorporated into it some of the same ingredients that can ultimately culminate in the so called "honor" killing of a wife. Such "honor" killings are a widespread phenomenon in many what are still basically traditional tribal societies, including most tribal Muslim societies and others as well. It is a values system commonality that is shared between them. It should be noted, however, that "honor" killings are not by definition a Muslim issue, but rather one originating in ancient tribal customs predating Islam in many parts of the world and its cultures.

\footnotetext{
“Although honor killings are typically associated with Muslim countries like Turkey, Iraq and especially
} 
Pakistan, the practice has nothing to do with Islam. Rather, it is rooted in ancient tribal customs whereby the honor of a family or a whole village is represented by the morality, chastity and proper behavior of its women. Any perceived violation of that sense of honor often leads to deadly consequences" [17].

With the tribal/clan societal networks that prevail in Mongolia, as in many other clan and tribal based societies, misogynistic violence is often condoned as so called matters of honor. The "honor" saving misogynistic domestic violence against women in Mongolia, as well as misogynistic violence for other reasons can be carried out as previously stated with near certain impunity or minimal legal consequences [16].

It is and can be argued by some that violence against women in Mongolia can be blamed on conditions of increasing poverty caused by socio-economic inequalities resulting from modernization, nevertheless:

"As is a common feature in many countries, Mongolian commentators often link domestic and family violence with poverty, alcohol, poor housing and social conditions. However, again as is found elsewhere, research by women's NGOs has also shown its prevalence in more affluent households. The Mongolian MDG report also goes on to state that "Decision makers, political leaders, and members of the private sector, who are predominantly male, lack sensitivity, knowledge and awareness regarding domestic violence, especially violence against women" [18].

It is also important to note that domestic violence against women in Mongolia, for whatever reason or excuse, is a well kept cultural secret because of the social stigma and shame attached to it which causes a perceived loss of honor for the woman victim and disgrace for her family. According to a Mongolian saying: "A broken or cracked bone is better than lost honor or reputation." Traditional proverbs such as these are indicative of the value placed on the concepts of honor and of "saving face" in Mongolian society. Such traditional values are often strengthened when societies, including in Mongolia, come under stress from disruptive rapid industrialization and modernization.

\section{References}

[1] (2013) The World Factbook. US CIA. https://www.cia.gov/library/publications/the-world-factbook/geos/mg.html

[2] (2012) Mongolia. Country Background Notes, US Department of State. http://www.state.gov/r/pa/ei/bgn/2779.htm

[3] Diener, A. (2005) Mongols, Kazakhs, and Mongolian Territorial Identity: Competing Trajectories of Nationalization. Central Eurasian Studies Review, 4. http://www.bbc.co.uk/tribe/tribes/darhad/index.shtml

[4] Shamanism. Mircea Eliade. http://en.wikipedia.org/wiki/Shamanism

[5] (2007) Mongolia. Amnesty International Annual Report. http://thereport.amnesty.org/document/15

[6] Islamic Population Worldwide. http://www.islamicpopulation.com/asia/Mongolia/Islam\%20in\%20Mongolia.htm

[7] (2009) Mongolia: Ethnic Kazakhs Eye Land of Opportunity to the West. UNHCR. http://www.unhcr.org/refworld/docid/4b067562c.html

[8] (2013) Uighurs. The New York Times. http://topics.nytimes.com/top/reference/timestopics/subjects/u/uighurs_chinese_ethnic_group/index.html

[9] (2007) Mongolia. Country Reports on Human Rights Practices 2006, The Bureau of Democracy, Human Rights, and Labor.

[10] (2012) 2011 Country Reports on Human Rights Practices-Mongolia. UNHCR, US Department of State. http://www.unhcr.org/refworld/topic,4565c22532,4655a1462,4fc75a7c5f,0,,ANNUALREPORT,MNG.html

[11] (2011) State of the World's Minorities and Indigenous Peoples 2011-Mongolia. Minority Rights Group International. http://www.unhcr.org/refworld/topic,4565c2253b,4565c25f473,4e16d36711,0,,MNG.html

[12] Rossabi, M. (2005) Modern Mongolia: From Khans to Commissars to Capitalists. University of California Press, Berkeley.

[13] (2012) Stop Violence against Women. The Advocates for Human Rights, US State Department. http://www.stopvaw.org/mongolia.html

[14] Trafficking in Persons Report 2011, US Department of State. www.state.gov/j/tip/rls/tiprpt/2011/164232.htm

[15] (2011) 2010 Human Rights Report: Mongolia, US State Department. http://www.state.gov/j/drl/rls/hrrpt/2010/eap/154394.htm

[16] (2012) The Advocates for Human Rights. http://www.stopvaw.org/mongolia 
[17] (2012) Honor Killings: An Ancient Ritual in a Modern World, Palash Gosh. International Business Times. http://www.ibtimes.com/honor-killings-ancient-ritual-modern-world-213893

[18] (2005) Modern Nomads: Women in Mongolia. Helen Jones Ph.D., Manchester Metropolitan University. http://www.europeangroup.org/sites/default/files/HelenJonespaper.doc 